Jurnal DISASTRI (Pendidikan Bahasa dan Sastra Indonesia)

Volume 3, Nomor 2, Agustus 2021| P-ISSN : 2716-4114 | E-ISSN: 2722-3329

\title{
LANGUAGE SKILLS OF DEAF CHILDREN AT JOMBANG STATE EXCEPTIONAL SCHOOL
}

\author{
Heny Sulistyowati ${ }^{1}$, Nur Hanifah ${ }^{3}$ \\ ${ }^{1,2}$ STKIP PGRI Jombang
}

\section{Corresponding Author: ${ }^{1}$ heny.sulistyowati@gmail.com}

\begin{abstract}
Deaf children show hearing difficulties from mild to severe categories, classified into hearing loss and deafness. Deaf people are people who have lost the ability to hear so that it hinders the process of language information through hearing, either using or not using hearing aids where the hearing limit they have is sufficient to allow the success of the process of language information through hearing. Deaf children need learning media in the form of teaching aids to enrich their language vocabulary. The props include miniature animals, human miniatures, relevant pictures, illustrated library books, and children's play tools. The method used in this study is a qualitative descriptive method through an observation. Observations are carried out in stages over several days starting from making an approach to making direct observations of objects. The results of observations made to Agus are guided by 4 language skills. Based on the four language skills, the object is able to master in writing skills. Listening skills are not mastered because the object has problems in hearing but can be overcome by the lip motion method. Object reading skills can understand but difficult to convey as well as speaking skills.
\end{abstract}

Key words: deafness, language skills

\section{KETERAMPILAN BERBAHASA ANAK TUNA RUNGU DI SEKOLAH LUAR BIASA NEGERI JOMBANG}

\begin{abstract}
Abstrak
Anak Tunarungu menunjukkan kesulitan mendengar dari kategori ringan sampai berat, digolongkan ke dalam kurang dengar dan tuli. Tunarungu adalah orang yang kehilangan kemampuan mendengar sehingga menghambat proses informasi bahasa melalui pendengarannya, baik memakai ataupun tidak memakai alat bantu dengar dimana batas pendengaran yang dimilikinya cukup memungkinkan keberhasilan proses informasi bahasa melalui pendengaran. Anak tunarungu memerlukan media belajar berupa alat peraga untuk memperkaya perbendaharaan bahasa. Alat-alat peraga itu antara lain miniatur binatang-binatang, miniatur manusia, gambar-gambar yang relevan, buku perpustakaan yang bergambar, dan alat-alat permainan anak.

Metode yang digunakan dalam penelitian ini adalah metode deskriptif kualitatif melalui suatu observasi. Observasi dilaksanakan secara bertahap dalam beberapa hari mulai dari melakukan pendekatan sampai melakukan observasi langsung kepada objek. Hasil observasi yang dilakukan kepada Agus dengan berpedoman kepada 4 keterampilan bahasa. Berdasarkan empat keterampilan berbahasa, objek mampu menguasai dalam keterampilan menulis. Keterampi;an menyimak kurang dikuasai karena objek bermasalah dalam pendengaran namun dapat diatasi dengan metode gerak bibir. Keterampilan membaca objek dapat memahami tapi kesulitan untuk menyampaikan begitu juga keterampilan berbicara.
\end{abstract}

Kata Kunci: tuna rungu, keterampilan bahasa

\section{Pendahuluan}

Manusia diciptakan dengan berbedabeda keadaan, terkadang ada yang sempurna dan ada yang kurang beruntung atau sama dengan tidak sempurna. Kesempurnaan tidak dilihat dari fisik saja namun juga kelebihan yang dimiliki. Terkadang ada yang fisik sempurna tapi pikiran lemah sebaliknya ada juga yang fisik kurang sempurna tapi memiliki kelebihan yang orang lain tidak memiliki. 


\section{Jurnal DISASTRI (Pendidikan Bahasa dan Sastra Indonesia) \\ Volume 3, Nomor 2, Agustus 2021| P-ISSN : 2716-4114 | E-ISSN: 2722-3329}

Keadaan fisik bisa dilihat dari alat indra yang dimiliki misalnya mata, hidung, telinga lidah, kulit. Salah satu alat indra apabila berbeda akan mengalami kecacatan sehingga menimbulkan kondisi yang menyimpang dari manusia pada umumnya atau yang disebut dengan kelainan.

Salah satu kelainan bisa disebabkan oleh telinga sehingga menimbulkan masalah dalam hal pendengaran yang dapat menghambat dalam berkomunikasi dengan orang lain. Hambatan yang disebabkan oleh telinga biasanya disebut dengan tuna rungu. Tuna rungu, yaitu individu yang memiliki hambatan dalam pendengaran permanen maupun temporer (tidak permanen). Soemantri (199:23) menyatakan bahwa tunarungu dapat diartikan sebagai suatu keadaan kehilangan pendengaran yang mengakibatkan seseorang tidak dapat menangkap berbagai rangsangan, terutama melalui indera pendengaran.

Tuna rungu adalah mereka yang pendengarannya tidak berfungsi sehingga membutuhkan pelayanan pendidikan luar biasa. Individu yang kurang pendengarannya atau tipe gangguan pendengaran yang lebih ringan dapat diatasi oleh alat bantu dengar dan individu ini bukan merupakan sasaran utama pendidikan bagi penyandang tunarungu karena individu tersebut masih bisa dibantu secara medis dan psikologis agar dapat mengikuti pendidikan biasa di sekolah normal. Anak tunarungu yang memiliki hambatan dalam pendengaran akibatnya individu tunarungu memiliki hambatan dalam berbicara sehingga mereka biasa disebut tunawicara. Cara berkomunikasi seseorang yang menyandang tuna rungu dengan individu lain yaitu menggunakan bahasa isyarat, untuk abjad jari telah dipatenkan secara internasional sedangkan untuk isyarat bahasa berbeda-beda di setiap negara.

Seorang anak yang mengalami masalah dalam hal pendengaran secara otomatis akan mempengaruhi kemampuannya dalam berbicara. Seperti yang diungkapkan oleh Somad (1996:29) akibat dari ketunarunguan ialah hambatannya dalam berkomunikasi, dimana komunikasi merupakan kegiatan yang sangat penting dalam kehidupan sehari-hari. Gangguan komunikasi tersebut mengakibatkan anak sulit mendengar yang dilanjutkan kesulitan dalam berbicara yang biasa disebut tuna rungu-wicara. Hambatan tersebut tentunya akan mengakibatkan ketidakmampuan anak penderita tunarungu wicara dalam melakukan interaksi sosial di masyarakat dan saat proses belajar di sekolah.

Dilihat dari masalah yang dialami anak tunarungu-wicara tentunya itu sangat berpengaruh dalam hal pendidikan, khususnya pada saat proses kegiatan belajar. Hal ini dapat dibandingkan dengan anak normal pada umumnya, anak tunarunguwicara akan mengalami keterlambatan dalam menerima pelajaran yang disampaikan oleh guru. Hal tersebut diakibatkan kurang maksimalnya kinerja indra penyandang tunarungu-wicara memiliki alat bahasa berupa bahasa isyarat, serta metode baca bibir ketika menerima materi dari guru.

Berdasarkan latar belakang tersebut peneliti melakukan penelitian yang terkait dengan tuna rungu wicara di SLB Negeri Jombang. Hal yang akan dibahas dalaini yaitu Tujuan penelitian ini adalah untuk mengetahui empat keterapilan berbahasa anak tuna rungu. Urgensi penelitian adalah bagaimana hasil yang didapat setelah dilakukan observasi kepada salah satu objek yang mengalami tuna rungu wicara di Sekolah Luar Biasa Negeri Jombang

\section{Landasan Teori}

Secara etimologi psikolinguistik terbentuk dari kata psikologi danlinguistik. Slobin (dalam Chaer, 2003: 5) mengemukakan bahwa psikolinguistik mencoba menguraikan proses-proses psikologi yang berlangsung jika seseorang mengucapkan kalimat-kalimat yang didengarnya pada waktu berkomunikasi dan bagaimana kemampuan bahasa diperole manusia.Menurut Dardjowidjojo (2003:21) Psikolinguistik adalah studi tentangp rosesproses mental dalam pemakaian bahasa, sebelum menggunakan Bahasa seorang pemakai bahasa terlebih dahulu memperoleh bahasa. Secara rinci psikolinguistik mempelajari empat topik utama yaitu (1) komprehensi, yakni proses-proses mental yang dilalui oleh manusia sehingga mereka dapat menangkap apa yang dikatakan orang dan memahami apa yang dimaksud, (2) produksi, yakni proses mental pada diri kita 
yang membuat seseorang dapat berujar seperti yang kita ujarkan, (3) landasan biologis dan neurologis yang membuat manusia bisa berbahasa, dan (4) pemerolehan bahasa, yakni bagaimana anak memperoleh bahasa.

\section{Menurut Chaer (2003: 6) ilmu \\ psikolinguistik \\ mencoba}

menguraikaprosesproses psikologi yang berlangsung jika seseorang mengucapkan kalimayang didengarnya pada waktu berkomunikasi, dan bagaimana kemampuan berbahasa itu diperoleh oleh manusia. Dapat dikatakan bahwa psikolinguistik mencoba menerangkan hakikat struktur bahasa, dan bagaimana struktur ini diperoleh, digunakan pada waktu bertutur, dan pada waktu memahami kalimat- kalimat dalam pertuturan itu. Dalam praktiknya, psikolinguistik mencoba menerapkan pengetahuan linguistik dan psikologi pada masalah-masalah seperti pengajaran dan pembelajaran bahasa, pengajaran bahasa permulaan dan membaca lanjut, kedwibahasaan dan multibahasa, gangguan berbahasa seperti cadel, gagap, latah dan sebagainya, serta masalah-masalah sosial lain yang menyangkut bahasa.

Berbahasa adalah proses mengeluarkan pikiran dan perasaan (dari otak) secara lisan, dalam bentuk kata-kata atau kalimat-kalimat. Manusia yang normal fungsi otak dan alat bicaranya, tentu dapat berbahasa dengan baik. Siswa yang memiliki kelainan fungsi otak dan alat bicaranya, tentu mempunyai kesulitan dalam berbahasa, baik produktif maupun reseptif. Jadi, kemampuan berbahasanya terganggu (Chaer, 2009: 148).

Gangguan berbahasa ini secara garis besar dapat dibagi dua. Pertama, gangguan akibat faktor medis dan kedua, akibat faktor lingkungan sosial. Yang dimaksud dengan faktor medis adalah gangguan, baik akibat kelainan fungsi otak maupun akibat kelainan alat-alat bicara, sedangkan yang dimaksud dengan faktor lingkungan sosial adalah lingkungan kehidupan yang tidak alamiah manusia, seperti tersisih atau terisolasi dari lingkungan kehidupan masyarakat manusia yang sewajarnya (Chaer, 2009: 148).

Secara medis menurut Sidharta (dalam Chaer, 2009:149) gangguan berbahasa itu dapat dibedakan atas tiga golongan, yaitu gangguan berbicara, gangguan berbahasa, gangguan berpikir. Ketiga gangguan itu masih dapat diatasi kalau penderita gangguan itu mempunyai daya dengar yang normal; bila tidak, tentu menjadi sukar atau sangat sukar.

Dalam memperoleh keterampilan berbahasa biasanya kita melalui suatu hubungan urutan yang teratur: mula-mula pada masa kecil kita belajar menyimak/mendengar bahasa, kemudian berbicara, membaca, dan menulis. Dengan demikian, rangkaian pemerolehan keterampilan berbahasa yaitu keterampilan menyimak, berbicara, membaca, kemudian menulis. Keterampilan berbahasa (Language Skills) mencakup empat keterampilan, yaitu 1) keterampilan menyimak (Listening Skills), 2) keterampilan berbicara (Speaking Skills), 3) keterampilan membaca (Reading Skill), dan 4) keterampilan menulis (Writing Skills). Winarsih mengemukakan bahwa tunarungu adalah suatu istilah umum yang menunjukkan kesulitan mendengar dari yang ringan sampai berat, digolongkan ke dalam tuli dan kurang dengar.

Orang tuli adalah yang kehilangan kemampuan mendengar sehingga menghambat proses informasi bahasa melalui pendengaran, baik memakai ataupun tidak memakai alat bantu dengar dimana batas pendengaran yang dimilikinya cukup memungkinkan keberhasilan proses informasi bahasa melalui pendengaran. Lebih lanjut dijelaskan tunarungu dapat diartikan sebagai keadaan dari individu yang mengalami kerusakan pada indera pendengaran sehingga menyebabkan tidak bisa menangkap berbagai rangsang suara, atau rangsang lain melalui pendengaran (Laila, 2013: 10).

Menurut

Dwidjosumarto mengemukakan bahwa seseorang yang tidak atau kurang mampu mendengar suara dikatakan tunarungu. Ketunarunguan dibedakan menjadi dua kategori, yaitu tuli (deaf) atau kurang dengar (hard of hearing) (Laila, 2013: 10). Winarsih mengemukakan bahwa tunarungu adalah suatu istilah umum yang menunjukkan kesulitan mendengar dari yang ringan sampai berat, digolongkan ke dalam tuli dan kurang dengar.

Tunarungu adalah istilah yang menunjuk pada kondisi ketidakfungsian organ pendengaran atau telinga seseorang anak. 


\section{Jurnal DISASTRI (Pendidikan Bahasa dan Sastra Indonesia) \\ Volume 3, Nomor 2, Agustus 2021| P-ISSN : 2716-4114 | E-ISSN: 2722-3329}

Kondisi ini menyebabkan mereka memiliki karakteristik yang khas, berbeda dari anak normal pada umumnya. Beberapa karakteristik anak tunarungu di antaranya adalah: a. Segi Fisik 1) Cara berjalannya kaku dan agak membungkuk akibat terjadinya permasalahan pada organ keseimbangan di telinga. 2) Pernapasannya pendek dan tidak teratur. 3) Cara melihatnya agak beringas. Penglihatan merupakan salah satu indra yang paling dominan bagi anak-anak penyandang tunarungu karena sebagian besar pengalamannya diperoleh melalui penglihatan.

Anak tunarungu mempelajari sekitarnya dengan menggunakan penglihatannya, maka akan timbul sifat ingin tahu yang besar, seolah-olah mereka haus untuk melihat, dan hal itu semakin membesarkan egosentrismenya.

Mempunyai perasaan takut akan lingkungan yang lebih luas Perasaan takut yang menghinggapi anak tunarungu seringkali disebabkan oleh kurangnya penguasaan terhadap lingkungan yang berhubungan dengan kemampuan berbahasanya yang rendah.

Keadaan menjadi tidak jelas karena anak tunarungu tidak mampu menyatukan dan menguasai situasi yang baik. 3) Ketergantungan terhadap orang lain Sikap ketergantungan terhadap orang lain atau terhadap apa yang sudah dikenalnya dengan baik, merupakan gambaran bahwa mereka sudah putus asa dan selalu mencari bantuan serta bersandar pada orang lain. 4) Perhatian mereka lebih sukar dialihkan Sempitnya kemampuan berbahasa pada anak tunarungu menyebabkan sempitnya alam pikirannya.Alam pikirannya selamanya terpaku pada hal-hal yang konkret.

\section{Mete Penelitian}

Jenis penelitian yang digunakan adalah penelitian kualitatif dengan pendekatan deskriptif naturalistik. Hal ini dijelaskan oleh Bogdan dan Tylor (Moleong, 2011: 4) bahwa penelitian kualitatif menghasilkan data deskriptif berupa data tulis atau lisan dari orang-orang dan perilaku yang dapat diamati definisi ini memiliki kaitan dengan penelitian deskriptif, yakni merupakan metode yang bertujuan membuat deskriptif berupa gambaran, lukisan secara otomatis, faktual, dan akurat mengenai data, sifat-sifat serta hubungan fenomenafenomena yang diteliti (Djasudarma, 2010: 9). Gall dan Borg (2003: 287) menyebutkan bahwa ciri umum dari sebuh penelitian deskriptif adalah melibatkan tentang tingkah laku, aspek kognitif dan hal lainnya tanpa interverensi dari peneliti atau dalam penelitian ini tidak ada campur tangan peneliti pada objek yang sedang diteliti (naturalistik). Pengumpulan data dalam penelitian ini dilakukan dengan cara

1) observasi: peneliti melakukan observasi di SLBN Jombang;

2) penentuan objek: objek diberikan oleh guru sesuai dengan kelompok/tingkatan sekolah

3) identifikasi data: peneliti menandai keterampi;an yang dikuasai siswa dan keterampi;an yang tidak dikuasai siswa.

4) kodifikasi: setelah data terkumpul kemudian diberi kode sesuai empat keterampilan berbahasa.

Sumber data penelitian adalah siswa tuna rungu di Sekolah Luar Biasa Negeri Jombang.. Dengan demikian sumber data dalam penelitian ini adalah siswa SLB Negeri Jombang yang bernama Agus Cahyono yang berusia 15 tahun menginjak bangku kelas 2 SMP. Data dalam penelitian ini adalah berupa empat keterampilan berbahasa berupa kosa kata dan kalimat.

\section{Hasil dan Pembahasan}

\section{A. Biodata Subjek Penelitian}

Objek penelitian ini bernama Agus Cahyono yang berusia 15 tahun duduk di bangku kelas 2 SMP LB. Agus adalah seorang anak yang mengalami keterbelakangan mental dan dia tidak bisa mendengar dan tidak bisa berbicara atau yang disebut tuna rungu wicara. Peneliti melakukan observasi mendatangi Agus dan bertatap muka langsung namun tetap memperhatikan protokol kesehatan mengingat masih dalam masa Pandemi covid-19.

\section{B. Deskripsi Hasil}

Situasi Pandemi tidak memungkinkan peneliti melakukan di sekolah. Pertama peneliti terlebih dahulu mendatangi rumah objek ditemani dengan guru yang 
mengajar Agus yang bernama Bapak Adi untuk membantu meminta izin kepada orang tua Agus agar diperbolehkan melakukan observasi langsung kepada Agus. Peneliti memperkenalkan diri kepada Agus maksud dan tujuan kami mendatanginya dan dia pun merespon namun dengan bahasa isyarat. Dengan bantuan bapak Adi kami sedikit memahami apa yang dibicarakan Agus.

Observasi hari kedua dilakukan dengan pendekatan kepada Agus agar dia merasa nyaman dengan kedatangan kami dengan mengajaknya pergi ke rumah makan sambil berbincang-bincang. Penelitin minta Bapak Adi untuk mengajari bahasa isyarat agar mempermudah obrolan untuk berjaga-jaga meskipun Agus memiliki kemampuan bisa memahami ucapan kami dangan metode baca bibir. Observasi pun kami lakukan dengan patokan pedoman 4 keterampilan bahasa yaitu mengenai menyimak (mendengarkan), berbicara, membaca dan menulis.

\section{1) Perolehan Empat Keterampilan Berbicara}

a. Menyimak

Dalam hal menyimak peneliti menguji dengan cara membacakan sebuah kalimat terhadap Agus dan hasilnya pun apabila kami berbicara cepat dia tidak bisa menangkap ucapan kami namun apabila dengan pelan dia bisa menangkap. Agus mampu menangkap dengan gerakan bibir saat kami membacakan kalimat tersebut. Hal ini sesuai dengan pemahaman menyimak sendiri yaitu Semakin fokus kita dalam menyimak dan semakin beragam latar belakang pembicara, maka keterampilan berbahasa kita dalam menyimak atau mendengar dapat semakin terasah.

b. Berbicara

Dalam berbicara dia menggunakan bahasa isyarat karena memang media komunikasi bagi para penyandang tuna rungu wicara.

c. Membaca

Dalam hal membaca dia mengetahui tapi susah untuk diucapkan karena memang dia mengalami kesulitan dalam berbicara sehingga susah menyampaikan hasil yang dibaca karena memang keseharian memakai bahasa isyarat namun dia memahami bacaan tersebut. Dia bisa membaca dan otak berusaha mencerna informasi-informasi dan mengimitasinya,

d. Menulis

Dalam menulis Objek menguasai huruf abjad bahkan hasil tulisannya sangat bagus. tulisan yang bagus adalah tulisan yang mudah dicerna melalui penggunaan kalimat-kalimat yang sederhana, efektif, dan efisien. Ketika seseorang dapat dengan mudah memahami pokok bahasan suatu tulisan, maka tulisan itu dapat dianggap bagus karena ditulis dengan terampil. Keterampilan menulis pun tidak dapat tumbuh sendiri tanpa adanya penguasaan keterampilan berbahasa yang lain.

Hasil penelitian dari 4 ketrampilan bahasa Agus hanya mampu menguasai 3 keterampilan bahasa yaitu dalam hal menulis. Menyimak kurang menguasai karena memang dia bermasalah dalam pendengaran namun dapat diatasi dengan metode gerak bibir. Untuk membaca dia memahami tapi kesulitan untuk menyampaikan dan tidak menguasai keterampilan bahasa dalam aspek berbicara.

Pada umur 1 tahun Agus baru diketahui mengalami gangguna berbicara. Agus secara fisik normal ketika dilihat orang-orang hanya saja Agus tidak bisa bicara. Berdasarkan pengamatan kami Agus mampu berinteraksi dengan baik pada orang terdekat atau dengan temantemannya, tetapi pada saat kami mengajak interaksi Agus terlihat malumalu. Agus berinteraksi menggunakan bantuan buku atau HP ketika lawan bicaranya tidak mengerti apa yang di bicarakan Agus. Berikut hasil pembahasan mengenai masalah keterampilan bahasa yang dimiliki Agus. 
Jurnal DISASTRI (Pendidikan Bahasa dan Sastra Indonesia)

Volume 3, Nomor 2, Agustus 2021| P-ISSN : 2716-4114 | E-ISSN: 2722-3329

\begin{tabular}{|c|c|}
\hline $\begin{array}{l}\text { Keterampilan } \\
\text { Berbahasa }\end{array}$ & Analisis \\
\hline Menyimak & 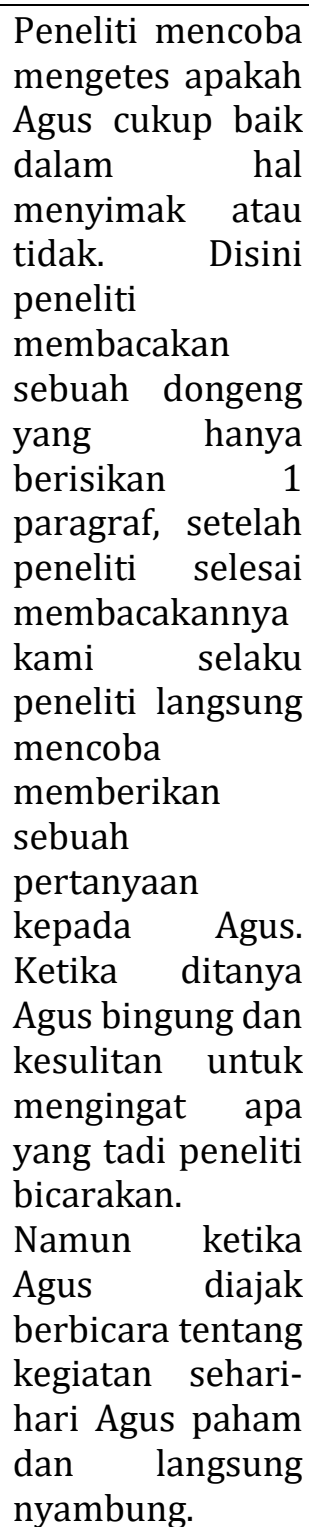 \\
\hline Berbicara & $\begin{array}{l}\text { Karena Agus } \\
\text { adalah anak tuna } \\
\text { wicara jadi dalam } \\
\text { hal berbicara } \\
\text { agus tidak bisa } \\
\text { namun bukan } \\
\text { berarti tidak bisa } \\
\text { berbicara, Agus } \\
\text { masih bisa } \\
\text { berucap hanya } \\
\text { beberapa kata } \\
\text { meskipun tidak } \\
\text { jelas. Misalnya } \\
\text { penghilangan } \\
\text { suka kata depan } \\
\text { kata "pepe" yang } \\
\text { artinya tempe, }\end{array}$ \\
\hline
\end{tabular}

\begin{tabular}{|c|c|}
\hline & $\begin{array}{l}\text { kata "wak" yang } \\
\text { maksudnya iwak } \\
\text { atau dalam } \\
\text { bahasa Indonesia } \\
\text { atinya ikan. Agus } \\
\text { berinteraksi } \\
\text { menggunakan } \\
\text { bantuan buku } \\
\text { atau HP ketika } \\
\text { lawan bicaranya } \\
\text { tidak mengerti } \\
\text { apa yang di } \\
\text { bicarakan Agus. }\end{array}$ \\
\hline Mem & $\begin{array}{lr}\text { Untuk } & \text { membaca } \\
\text { sama } & \text { halnya } \\
\text { berbicara. } & \text { Agus } \\
\text { tidak } & \text { bisa } \\
\text { membaca, } & \text { Agus } \\
\text { hanya } & \text { bisa } \\
\text { membaca } & \text { dalam } \\
\text { hati. } & \end{array}$ \\
\hline Mer & 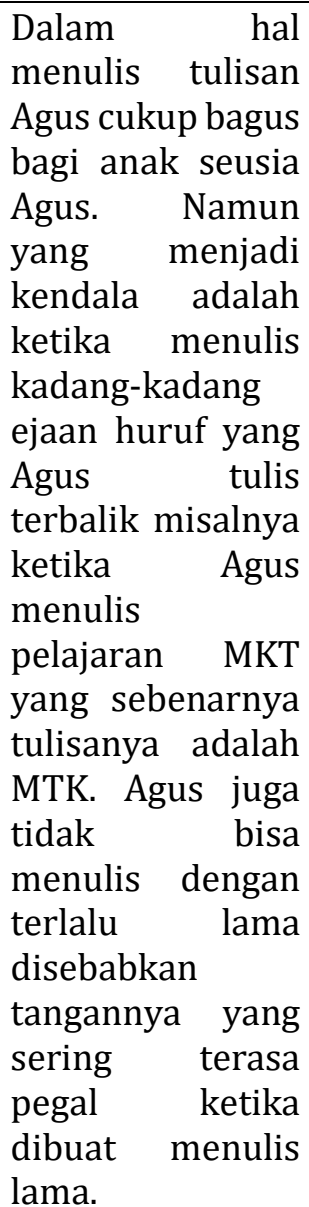 \\
\hline
\end{tabular}

Dari tabel diatas dapat disimpulkan bawasannya Agus lebih paham apabila menyimak seseorang yang sedang bertanya 


\section{Jurnal DISASTRI (Pendidikan Bahasa dan Sastra Indonesia) \\ Volume 3, Nomor 2, Agustus 2021| P-ISSN : 2716-4114 | E-ISSN: 2722-3329}

kesehariannya atau membicarakan hal-hal yang tidak berbau menuntut. Peneliti mencoba membacakan cerita pendek yang menuntun Agus untuk menyimak dengan baik agar bisa mengingat. Dalam hal berbicara dan membaca Agus tidak bisa karena Agus adalah anak tuna wicara Agus hanya bisa berucap Pepe yang artinya tempe dan wak yang artinya iwak. Sedangkan dalam hal menulis Agus termasuk golongan anak-anak pada umumnya tulisannya masih bisa dibaca dan bagus, namun Agus tidak bisa jika menulis terlalu lama. Tangannya yang sering terasa sakit membuat Agus harus sering berhenti apabila disuruh menulis terlalu banyak.

\section{Simpulan}

Berdasarkan hasil penelitian Keterampilan Berbahasa Anak Tuna Rungu SLB Negeri Jombang maka dapat disimpulkan sebagai berikut. Agus secara fisik normal ketika dilihat orang-orang hanya saja Agus tidak bisa mendengar dan berbicara. Berdasarkan pengamatan Peneliti, Agus mampu berinteraksi dengan baik pada orang terdekat atau dengan teman-temannya, tetapi pada saat peneliti mengajak interaksi Agus terlihat malu-malu. Pada saat berinteraksi menggunakan bantuan buku atau HP ketika lawan bicaranya tidak mengerti apa yang dibicarakan. Berdasarlan pengamatan dan observasi Agus mempunyai masalah pada keterampilan bahasa yaituketerampilan berbicara dan membaca sedangkan dalam hal keterampilan menulis kadang-kadang Ejaan huruf yang ditulis terbalik. Keterampilan menyimak masih bisa mendengarkan, tetapi ketika ditanya seputar dongeng yang dibacakan peneliti, masih terlihat kebingungan.

\section{DAFTAR PUSTAKA}

Abdurrahman, Mulyono. 2010. Pendidikan Bagi Anak Berkesulitan Belajar (Education for Children with Learning Difficulties) . Jakarta: Rineka Cipta

Badger, Julia R. et.al. 2020. The developmental trajectory of English conditional grammar in 4- to 11-year-old children. Journal of Child Language Acquisition and Development - JCLAD Vol:8 Issue: 11-21, 2020, March ISSN: 2148-19. jclad home (science-res.com)

Chaer, Abdul. 2009. Psikolinguistik Kajian Teoritik (Psycholinguistics in Theoretical Studies). Jakarta: Renika Cipta

Djajasudarma, Fatima. 2010. Metode Linguistik Ancangan Metode Penelitian dan Kajian. (Linguistic Method: Method Plan of Research and Study). Bandung: Refika Aditama

Efendi. 2006. Tips Menangani Siswa Yang Membutuhkan Perhatian Khusus (Tips for Handling Students Who Need Special Attention). Jakarta: Bumi Aksara

Litosseliti, Lia. 2010. Research methods in linguistics. London: Continum.

Mahsun. 2005. Metode Penelitian Bahasa (Language Research Method). Jakarta: Pt Raja Grafindo Puataka

Mar'at. 2011. Psikolingustik

(Psycholinguistics). Jakarta: Renika Cipta

Natsir. 2017. Hubungan Psikolinguistik dalam Pemerolehan dan Pembelajaran Bahasa. STIA YAPPI:Makassar

Tarigan Guntur, Henry. 2008. Membaca Sebagai Keterampilan Berbahasa (Reading as a language skill). Bandung: Angkasa 